\title{
BIMBINGAN BAGI IBU-IBU UNTUK MENGENAL MANFAAT JAMUR KONSUMSI DAN ANEKA VARIASI PENGOLAHANNYA
}

\author{
Daryanti *1, Tyas Soemarah KD $^{1}$, Endang Suprapti ${ }^{1}$, Agus Budiyono ${ }^{1}$, Teguh Supriyadi ${ }^{1}$, R. Soelistijono ${ }^{1}$ \\ 1 Fakultas Pertanian, Universitas Tunas Pembangunan \\ *e-mail: dyanti_utp@yahoo.co.id
}

\begin{abstract}
Abstrak
Bahan pangan berupa jamur atau yang disebut jamur konsumsi (jamur tiram, jamur kuping, jamur merang, dll.) sudah banyak dikenal masyarakat di Indonesia. Sebagai bahan pangan, jamur mempunyai keistimewaan yaitu kaya nutrisi, kaya serat, mengandung senyawa-senyawa yang berkhasiat untuk menangkal penyakit dan harganya cukup murah. Masyarakat umumnya mengenal jamur sebagai bahan makanan yang rasanya enak, bertekstur kenyal seperti daging tetapi banyak warga masyarakat yang belum mengetahui manfaat jamur bagi kesehatan. Oleh karena itu perlu dilakukan kegiatan untuk memberikan pemahaman tentang manfaat jamur bagi kesehatan dan cara pengolahan jamur yang bervariasi untuk meningkatkan minat masyarakat dalam mengkonsumsi jamur.Kegiatan pengabdian masyarakat ini bertujuan: 1. Memberikan pemahaman kepada ibuibu tentang manfaat jamur konsumsi untuk kesehatan dan khasiat senyawa dalam jamur untuk melawan penyakit, 2. Memberikan bimbingan aneka variasi pengolahan jamur. Kegiatan telah dilaksanakan di Desa Triyagan, Kecamatan Mojolaban, Kabupaten Sukoharjo pada bulan Desember 2021- Januari 2022. Kegiatan pengabdian diikuti oleh 50 orang ibu-ibu kader PKK Desa Triyagan. Materi pengabdian dapat diterima dengan baik dan menambah wawasan ibu-ibu tentang manfaat jamur dan cara pengolahannya. Aneka variasi olahan jamur yang diperkenalkan dalam kegiatan ini yaitu jamur krispi, sate jamur, sosis isi jamur dan bumbu kaldu bubuk jamur.
\end{abstract}

Kata Kunci : jamur konsumsi, manfaat, khasiat, pengolahan

\begin{abstract}
Abstrac
Foodstuffs in the form of mushrooms or so-called consumption mushrooms (oyster mushrooms, ear mushrooms, edible mushrooms, etc.) are widely known to the public in Indonesia. As a food ingredient, mushrooms have the privilege of being rich in nutrients, rich in fiber, containing compounds that are efficacious to ward off disease and the price is quite cheap. People generally recognize mushrooms as a food ingredient that tastes good, has a chewy texture like meat, but many people do not know the benefits of mushrooms for health. Therefore, it is necessary to carry out activities to provide an understanding of the benefits of mushrooms for health and the various ways of processing mushrooms to increase public interest in consuming mushrooms. This community service activity aims to: 1. Provide understanding to mothers about the benefits of consuming mushrooms for health and efficacy. compounds in mushrooms to fight disease, 2. Provide guidance on various variations of mushroom processing. The activity was carried out in Triyagan Village, Mojolaban District, Sukoharjo Regency in December 2021-January 2022. The service activity was attended by 50 women from Triyagan Village PKK cadres. The service material is well received and adds insight to the mothers about the benefits of mushrooms and how to process them. Various variations of mushroom preparations introduced in this activity are crispy mushrooms, mushroom satay, mushroom stuffed sausage and mushroom powdered broth seasoning.
\end{abstract}

Keywords: mushroom consumption, benefits, efficacy, processing

\section{PENDAHULUAN}

Bahan pangan berupa jamur atau yang disebut jamur konsumsi ada banyak macamnya yaitu jamur tiram, jamur kuping, jamur merang, jamur kancing. Jenis-jenis jamur tersebut sudah banyak dikenal masyarakat di Indonesia. Minat masyarakat untuk mengkonsumsi jamur menunjukkan peningkatan. Hal ini dapat dilihat dari semakin banyaknya jamur dijual di pasaran, bahkan sudah umum dijual oleh tukang sayur keliling. Meskipun demikian, minat masyarakat mengkonsumsi jamur belum sebanyak konsumsi sayuran jenis lainnya. 
Sebagai bahan pangan, jamur mempunyai keistimewaan yaitu kaya nutrisi, kaya serat, mengandung senyawa-senyawa yang berkhasiat untuk menangkal penyakit dan harganya cukup murah. Masyarakat umumnya mengenal jamur sebagai bahan makanan yang rasanya enak, bertekstur kenyal seperti daging tetapi banyak warga masyarakat yang belum mengetahui manfaat jamur bagi kesehatan.

Desa Triyagan, Kecamatan Mojolaban, Kabupaten Sukoharjo terletak kurang lebih 30 km arah Timur Kota Surakarta. Luas wilayah desa 168.4655 ha, dengan luas pekarangan 67,47 ha, tegalan 2,35 ha dan sawah 71,2 ha. Sawah berpengairan teknis dengan pola tanam padi-padi-palawija. Jumlah penduduk 6.615 orang, dengan mata pencaharian PNS 837 , ABRI 36, swasta 4.234 orang, dagang 83, tukang 68, pensiunan 87,tani dan buruh tani 1.275 orang (Monografi Desa Triyagan, 2021). Kegiatan PKK berjalan aktif di Desa Triyagan. Dari hasil survey diketahui ibu-ibu warga di Desa Triyagan, banyak yang belum mengetahui manfaat jamur bagi kesehatan. Cara mengolah jamur masih terbatas diolah menjadi oseng atau sup, padahal jamur bisa diolah menjadi aneka macam masakan kekinian seperti nugget, isian sosis, jamur crispy agar lebih menarik untuk dikonsumsi.

Pandemi corona yang sudah berlangsung cukup lama di Indonesia menimbulkan dampak berat di berbagai aspek kehidupan baik social, pendidikan, keagamaan dan terutama perekonomian masyarakat. Dari aspek ekonomi, banyak warga kehilangan pekerjaan atau semakin sulit mencari penghasilan sehingga menyebabkan menurunnya daya beli untuk mencukupi kebutuhan sehari-hari, tak terkecuali kebutuhan terhadap makanan yang bergizi. Makanan yang bergizi sangat penting untuk meningkatkan daya tahan terhadap penyakit. Masyarakat perlu memahami untuk pandai-pandai menyiasati agar bisa mengkonsumsi makanan bergizi dengan harga yang terjangkau. Dalam hal ini, jamur bisa menjadi alternative sebagai bahan pangan kaya gizi yang harganya lebih murah dibanding pangan hewani seperti daging atau ikan, dan mempunyai keistimewaan berkhasiat melawan aneka penyakit.

Dalam kegiatan pengabdian masyarakat ini diberikan penyuluhan untuk meningkatkan pengetahuan masyarakat khususnya ibu-ibu di Desa Triyagan, tentang manfaat dan khasiat jamur bagi kesehatan serta bimbingan cara pengolahan jamur yang bervariasi untuk meningkatkan minat dalam mengkonsumsi jamur.

\section{METODE}

Kegiatan pengabdian masyarakat dilaksanakan di Desa Triyagan, Kecamatan Mojolaban, Kabupaten Sukoharjo, pada bulan Desember 2021- Januari 2022. Rangkaian kegiatan terdiri dari sosialisasi, persiapan bahan dan alat, pelaksanaan penyuluhan dan praktek pengolahan. Bahan yang digunakan terdiri dari jamur tiram, daging ayam, terigu, telur, sayuran (wortel, sledri), bumbu-bumbu (bawang Bombay, bawang putih, merica), minyak goreng. Peralatan antara lain terdiri dari wajan, panci, blender, wajan Teflon.

Peserta terdiri dari ibu-ibu kader PKK Desa Triyagan berjumlah 50 orang. Kegiatan dilaksanakan dengan menerapkan protokol kesehatan untuk mencegah bahaya Covid-19 yaitu selalu memakai masker, mencuci tangan sebelum dan sesudah kegiatan, menjaga jarak antar peserta.

\section{HASIL DAN PEMBAHASAN}

Kegiatan pengabdian masyarakat telah terlaksana dan mendapatkan respon yang baik dari para peserta. Meskipun ibu-ibu sudah tidak asing lagi dengan bahan pangan berupa jamur tetapi belum mengetahui tentang manfaat jamur bagi kesehatan. Materi penyuluhan diawali dengan pengenalan tentang jamur. Jamur konsumsi dalam pengelompokan bahan makanan termasuk jenis sayuran. Kepada peserta dijelaskan tentang aneka jenis jamur yaitu ada jamur edible yaitu jamur yang bisa dimakan atau jamur konsumsi, dan jamur non edible yaitu jamur yang tidak bisa dimakan. Jamur edible ada banyak jenisnya, diantara yang sudah 
dikembangkan secara komersial yaitu jamur merang, kancing, kuping, tiram, shiitake (Widiyastuti, 2002; Sinaga, 1994) . Jamur non edible meliputi jamur untuk obat misalnya lingzhi dan jamur beracun. Jamur beracun biasanya memiliki cincin atau cawan pada pangkal batangnya, jamur mengeluarkan bau busuk, jika dimasak warnanya berubah menjadi gelap (Anonim, 2004).

Jamur mengandung berbagai zat gizi seperti protein, lemak, karbohidrat, berbagai vitamin dan mineral. Jamur mengandung protein cukup tinggi dibanding bahan makanan lain dari tumbuhan, terutama dari jenis sayuran. Dalam hal lemak, jamur merupakan bahan makanan berlemak rendah. Sekitar 70\% dari asam lemak dalam jamur merupakan asam lemak tak jenuh. Asam lemak tak jenuh sangat dibutuhkan tubuh dan tidak berbahaya apabila dikonsumsi dalam jumlah besar. Hal ini berbeda dengan asam lemak jenuh yang biasanya terdapat pada hewan. Asam lemak jenuh apabila dikonsumsi dalam jumlah besar dapat membahayakan kesehatan.

Jamur juga mengandung berbagai macam vitamin, meskipun tidak mengandung vitamin A. Vitamin dalam jamur terutama kelompok vitamin B seperti thiamin, niasin, riboflavin. Jamur merupakan sumber mineral yang baik. Kandungan mineral terbesar pada jamur yaitu potassium, fosfor, sodium, kalsium, dan magnesium. Sedangkan mineral besi, seng, tembaga dan mangan terdapat dalam jumlah kecil.

Karbohidrat yang terdapat dalam jamur antara lain pentosa, heksosa, polisakarida. Polisakarida yang diekstrak dari tubuh buah jamur mempunyai khasiat dapat menghambat tumor. Jamur juga banyak mengandung serat. Kandungan serat pada jamur merang 4-20\% dan pada jamur kancing $10,4 \%$. Serat sangat diperlukan tubuh untuk membantu pencernaan, mempermudah buang air besar, mencegah penyakit wasir dan kanker usus, serta konsumsi serat yang tinggi juga dapat menurunkan kadar kolesterol dalam darah.

Khasiat jamur sebagai obat banyak sekali, yaitu dapat menurunkan kadar gula darah dan kolesterol, mencegah tumor dan kanker, menetralisir racun dalam makanan olahan, mencegah radang usus, menurunkan tekanan darah. Kandungan senyawa tertentu dalam jamur berkhasiat sebagai obat, misalnya pada jamur lingzhi mengandung asam genodermat dan genodermin yang berkhasiat sebagai antivirus, antikanker, dan menambah kebugaran tubuh. Pada jamur shiitake terkandung senyawa lentinan (suatu polisakarida larut air) yang berkhasiat sebagai antitumor. Jamur shiitake juga mengandung senyawa yang dapat menurunkan kadar kolesterol dan kadar gula dalam darah.

Khasiat jamur kuping sebagai obat yaitu terletak pada lendir yang keluar saat jamur ini dimasak. Lendir ini dipercaya dapat menetralkan kelebihan kolesterol dalam darah, dapat menetralkan racun jika masakan yang dibuat tercampur bahan yang mengandung racun seperti residu pestisida, deterjen, logam-logam berat. Jamur kuping dipercaya juga sebagai obat penyakit kurang darah, ambeien, darah tinggi, melancarkan sirkulasi darah, melancarkan menstruasi yang tidak teratur. Sedangkan jamur tiram, dengan kandungan proteinnya yang cukup tinggi, berpotensi sebagai bahan makanan sumber protein yang non kolesterol, sehingga dapat mencegah penyakit hipertensi dan serangan jantung (Widiyastuti, 2002; Soenanto, 2000).

Jamur bisa diolah menjadi aneka makanan yang lezat dan bergizi sebagai hidangan keluarga atau dijual sebagai suatu usaha yang mendatangkan penghasilan. Beberapa resep praktis olahan jamur yang diperkenalkan dalam kegiatan pengabdian ini yaitu : jamur krispi, sosis basah isi jamur, sate jamur, dan kaldu bubuk jamur(Mahasin, 2010). 

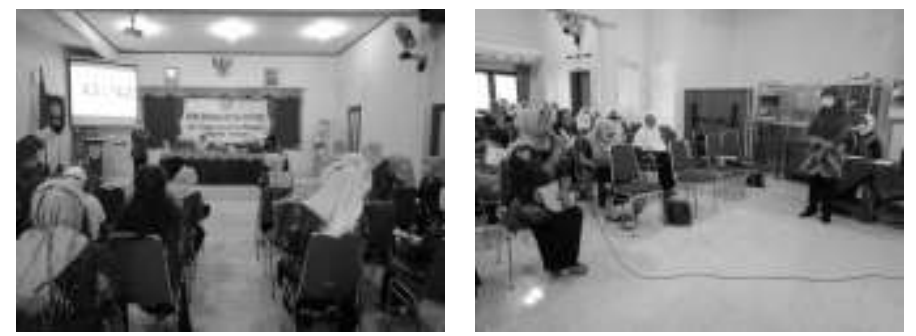

Gambar 1. Pemaparan materi dan sesi tanya jawab

Peserta cukup antusias dalam mengikuti tahap penyuluhan, terbukti dari adanya pertanyaan-pertanyaan yang diajukan para peserta. Pengetahuan yang diberikan tentang mengenal jenis-jenis jamur, manfaat jamur bagi kesehatan baik dari aspek gizi maupun khasiatnya dalam menangkal berbagai penyakit bisa dipahami dengan baik.

Pada kegiatan praktek, ibu-ibu tidak menemui kesulitan dalam mengolah jamur menjadi aneka makanan karena cukup mudah, bahan dan alat yang diperlukan mudah didapat dan sudah biasa digunakan sehari-hari. Hasil olahan langsung dinikmati bersama oleh para peserta dan ternyata rasanya lezat dan menimbulkan minat ibu-ibu untuk praktek sendiri di rumah.
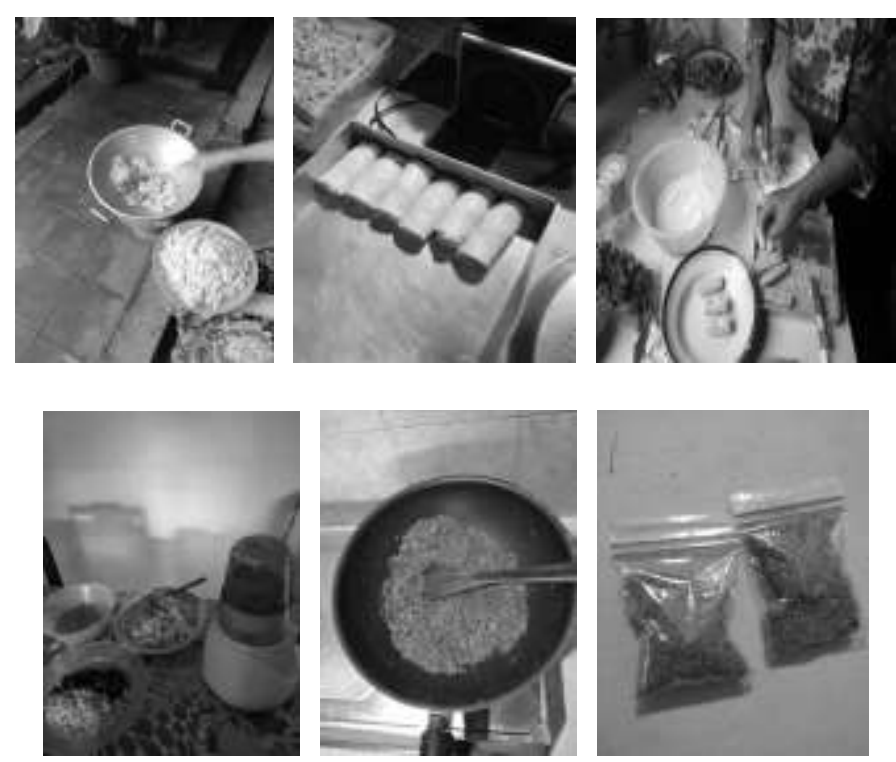

Gambar 2. Kegiatan praktek pengolahan jamur

Ibu-ibu sudah cukup familiar dengan bahan makanan dari jamur dan sudah biasa mengolah untuk hidangan keluarga di rumah. Tetapi dari penjelasan ibu-ibu, olahan yang dibuat baru beberapa macam yaitu oseng jamur dan sup jamur. Melalui kegiatan pengabdian ini kepada ibu-ibu diperkenalkan aneka variasi olahan jamur lainnya yaitu keripik jamur, jamur krispi, sosis basah isi jamur, sate jamur, nugget jamur dan kaldu bubuk jamur. Dengan olahan yang berviariasi dan pengetahuan tentang manfaat jamur untuk kesehatan, diharapkan bisa lebih menarik minat anggota keluarga untuk mengkonsumsi jamur. Dengan mengenal aneka variasi olahan jamur, diharapkan juga bisa menjadi ide untuk dikembangkan sebagai usaha sampingan untuk menambah pemasukan. Pengenalan cara pembuatan bumbu kaldu bubuk dari jamur bertujuan untuk memperkenalkan kepada ibu-ibu bahwa bumbu kaldu bubuk yang aman bagi kesehatan (non MSG) juga bisa dibuat sendiri di rumah dari bahan jamur. Proses pembuatan sosis isi jamur merupakan variasi membuat sosis yang biasanya isi sosis berupa daging ayam atau sapi. Dengan menggunakan jamur, menurut penilaian peserta 
hasil sosis juga terasa lezat, lebih ekonomis dan mempunyai keistimewaan yaitu mengandung serat dan non kolesterol. Hasil kegiatan ini diharapkan bisa ditularkan oleh para kader PKK kepada ibu-ibu di lingkungan RW atau RT masing-masing.

\section{KESIMPULAN}

Dari kegiatan pengabdian ini dapat disimpulkan :

1. Kegiatan pengabdian sudah terlaksana dengan baik dan mendapat sambutan baik dari peserta / para kader PKK di Desa Triyagan.

2. Materi yang disampaikan bisa menambah wawasan ibu-ibu tentang mengenal aneka jenis jamur, manfaat jamur dari segi gizi dan khasiat jamur dalam melawan penyakit.

3. Bisa menambah wawasan dan keterampilan ibu-ibu tentang cara mengolah jamur yang bervariasi.

\section{UCAPAN TERIMA KASIH}

Kegiatan pengabdian ini terlaksana atas dukungan dana dari Direktorat Riset dan Pengabdian Masyarakat Universitas Tunas Pembangunan Surakarta anggaran tahun 2021/2022, untuk itu diucapkan terimakasih yang sebesar-besarnya.

\section{DAFTAR PUSTAKA}

Anonim, 2004. Budidaya Jamur Konsumsi, Agromedia Pustaka, Jakarta.

Widiyastuti, B., 2002. Budidaya Jamur Kompos, Penebar Swadaya, Jakarta.

Soenanto, H., 2000. Jamur Kuping Budidaya dan Peluang Usaha, PT Pabelan Cerdas Nusantara, Solo.

Sinaga, M., 1994. Jamur Merang dan Budidayanya, Penebar Swadaya, Jakarta.

Mahasin, T., 2010. 18 Resep Variasi Olahan Jamur, Citra Media, Yogyakarta. 